\title{
THE IMPLICATIONS OF LEBANESE CULTURAL COMPLEXITIES FOR EDUCATION
}

\author{
LINDA AKL
}

\begin{abstract}
The numerous cultures that exist in Lebanon are in constant conflict. This paper tries to identify the extent to which multiculturalism influences the Lebanese educational system. The paper tries to develop possible solutions to the educational problems created by a multicultural Lebanese society by comparing and contrasting western liberal-secular educational ideologies. The solutions arise from an examination of: (i) the influence of Lebanon's politico-religious history on the national cultural identity; (ii) the infrastructure of Lebanese schools and universities; (iii) some politico-religious events in Lebanese educational institutions; and (iv) the multilingual society of Lebanon which manifests itself in patterns of social and academic behaviour.
\end{abstract}

\section{Introduction}

$\mathcal{L}$ ebanon has managed to survive numerous wars and internal conflicts. Its geostrategic position as a small country lying between Syria and Israel makes incursions by these opposing foreign powers inevitable. Lebanon still exists on the map but the fundamental quandaries remain. The consequences of the multiple Lebanese cultures and the ways in which they relate to one another and impact on the Lebanese educational system are unique and complex.

This paper provides a brief overview of the various entangled elements that underlie the Lebanese culture and explores their influence on the educational system. The purpose is to set a framework for future empirical research on the issues of equality within the Lebanese educational system. Since there is a limited amount of published research within the Lebanese context on this topic, this paper draws on constructs created by western cultural theorists. The author of this paper draws upon her own and others' personal experiences to exemplify some of these theories.

Culture symbolises the specialised lifestyle of a group of people (Devito, 2004) and 'can be thought of as a blueprint that guides the ways in which individuals within a group' (Biehler \& Snowman 2003, p. 145) perceive, believe, evaluate, value, share and work (Arends, Tannenbaum \& Winitzky, 2001; Eggen \& Kauchak, 2003; Femiano et al., 2005). In addition, when religion plays a prominent role in culture, it is difficult to separate the impact of religion from other 
cultural influences. Berger's (2003) comment that 'as soon as one looks at culture one is looking at religion' (p. 4) applies particularly to the Lebanese situation. Furthermore, language and culture are deeply intertwined and 'one cannot separate the two without losing the significance of either language or culture' (Iskold, 2002, p. 103). Thus, culture is a dynamic phenomenon that encompasses numerous, usually covert, variables. These underlying components appear to be the reason why cultural problems are not easily identified and solved. The importance of religion and language, and their effect on the formation of a culture, vary from one community to another. Lebanon is a good example of a country in which religion and language profoundly affect the evolution of the culture which, in turn, influences the educational system.

The Lebanese Republic is one of the most unusual states in the world, encompassing a melange of cultures. It is a conglomeration of paradoxes and contradictions. Lebanon as a polity is archaic, inefficient and divided; it is also democratic, traditional and modern (Hudson, 1985). As described by Harris (2006):

'Lebanon's story is a particularly rich and varied tapestry, encompassing sectarianism and class conflict, secularism and religious radicalism, Islam and Christendom, the Orient and the West, Sunni and Shi'a, Israel and the Arabs much else besides.' (p. 9)

Lebanon is a country with a mosaic of cultures, a linguistic kaleidoscope and a vivacious population. Lebanon is difficult to classify according to the usual typologies, it is a democracy, but it is also an oligarchy (Hudson, 1985).

The infrastructure of Lebanon and the coordination of its highly articulated subcultures create fundamental problems on various levels and in many organisations, including the educational system. Most of the research that deals with multicultural education has been designed by western writers who are guided by a liberal-secular ideology which fits into the cultural formation of their respective societies. In order to look at multiculturalism from an insider's point of view it is important to look at the various components of the Lebanese educational system. These include:

1. The foundation of the school system and its cultural implications.

2. The formal and the hidden curriculum.

3. The infrastructure of the Lebanese universities and their affiliations within a cultural context.

4. The politico-religious events that are taking place within educational settings. 
Furthermore, this paper will look at Lebanon's politico-religious history and Lebanese multilingualism in order to explore how they influence the development of a Lebanese national cultural identity.

\section{The influences of culture on educational systems}

It is difficult to challenge the view that culture impacts on learning (Evans, Schweingruber \& Stevenson, 2002; Eggen \& Kauchak, 2003; Armstrong, Henson $\&$ Savage, 2005). However, each culture influences pedagogy in a different way. Hofstede \& Hofstede (2005) generated a framework for defining some of the ways in which educational relationships are constructed in different cultural situations. At opposite ends of the continuum are the collectivist cultures and the individualist cultures. Collectivism pertains to societies where the interest of the group prevails over the interest of the individual, whereas individualism pertains to societies where the interest of the individual prevails over the interest of the group (Hofstede \& Hofstede, 2005). Western cultures tend to be individualistic, whereas most nonwestern cultures tend to be collectivist (Hogg \& Vaughan, 2002; Anjum et al., 2005).

In individualistic societies, multicultural education is dealt with by constructively using students' diverse backgrounds as enhancements instead of impediments (Eggen \& Kauchak, 2003; Armstrong, Henson \& Savage, 2005). In addition, the teacher's role is viewed as a mediator of cultural diversity (Arends, Tannenbaum \& Winitzky, 2001; Biehler \& Snowman, 2003). This western perspective on multicultural education can be labelled a 'liberal-secular ideology'. Many multicultural educational programmes for students are built upon this ideology (Kluth \& Straut, 2001; Barth, 2002; Gay, 2003; Schaps, 2003; Wolk, 2003; Shields, 2004; Albright \& Kugler, 2005; Bazron, Fleischman \& Osher, 2005; Bismilla et al., 2005; Napoliello \& Powell, 2005).

Furthermore, the liberal-secular ideology is a significant feature of national identities. For example, there is arguably a hegemonic culture evident in the UK and the USA. The dominant populations are white Anglo-Saxon, and English is the basic language. Therefore, it can be argued that there is a power-dominant view of what it means to be a citizen of the UK or the USA. Even though many subcultures exist within these two countries, there appears to be a dominant, albeit sometimes contested, national identity and language. Accordingly, the subcultures are at a disadvantage. This puts pressure on minority groups to integrate to the cultural hegemony. It is possible that this hegemonic culture drives liberalsecularists to deal with multicultural education in a way that is compatible with their cultural perspective. Therefore, these liberal-secular approaches to the educational field are easily applied in western cultures. 
In contrast to western individualistic cultures, Lebanon is characterised by collectivist cultural values (Hofstede \& Hofstede, 2005). Lebanese multiculturalism is fragmented to the extent that the notion of a national identity is highly contested. This is because there is no single dominant faction which promotes the development of a central Lebanese identity. When national identities are weak, national unities are threatened. In the absence of a hegemonic culture, conflict is difficult to resolve. The equivocal dominance of the Lebanese cultures lack constructive interaction except on functional levels. There are difficulties in communicating thoughts about the various cultural differences, which are at the core of the Lebanese quandaries. In exploring these issues, the author will refer to Barth's (2002) concepts of 'nondiscussables'. Some western concepts on multicultural education are of questionable value to Lebanese educational concepts. The reason being the liberal-secular argument that the diversity of students is something to be highlighted, acknowledged and explored rather than ignored.

The following are central to Hofstede \& Hofstede's (2005) account of the construction of educational relationships in collectivist societies:

- Students tend to speak up in class only when sanctioned by the group.

- Students from different ethnic backgrounds often form subgroups in class.

- Students from the same ethnic background as the teacher or other school officials tend to expect preferential treatment.

Whereas, these authors argue that in individualistic societies students expect to be treated as individuals and preferential treatment of students is considered nepotism. In addition, Hofstede \& Hofstede (2005) point out that collectivist cultures usually tend to have 'large power-distance' cultural dimensions. Powerdistance is defined as 'the extent to which the less powerful members of institutions and organizations within a country expect and accept that power is distributed equally' (Hofstede \& Hofstede, 2005, p. 46). Thus, in terms of relating the power dimension with educational relationships, these authors highlight the following features of educational settings in collectivist cultures:

- Authority resides with the teacher.

- The parent-child inequality is perpetuated by a teacher-student inequality.

- The educational process is teacher centred.

- In the classroom, there is strict order with the teacher initiating all communication.

- Teachers are never publicly contradicted or criticised and are treated with deference, even outside the school. 
There is a difference between the way multiculturalism is defined in western cultures and the way it is defined in eastern cultures. The use of the term multiculturalism in the West often refers to ethnic minorities, religious and racial differences, foreign students, and challenged or gifted students (O'Brien et al., 2003; Schaps, 2003; Albright \& Kugler, 2005; Bazron, Fleischman \& Osher, 2005; Bismilla et al., 2005; Napoliello \& Powell, 2005). In Lebanon, multiculturalism refers to similar types of diversity with the additional category of related political affiliations. Paradoxically, the Lebanese culture is characterised by the absence of a single dominant culture. In this paper it is argued that the Lebanese culture is in fact characterised by the presence of diverse and unintegrated subcultures. However, within these subcultures, the ethnic, religious and political components are deeply interwoven in such a way that ethnic identification is associated with linguistic identity and political and religious affiliations. Appendix A shows how the key elements of the Lebanese culture overlap. Furthermore, education systems are main functions of cultural reproduction. Their role is not to change the culture but rather to reproduce it harmoniously (Bernstein, 1970). Central to this paper is the argument that there is an absence of a national Lebanese identity to promote within schools. So each faction in the Lebanese society tends to reproduce its own culture in the schools that it organises in the diverse Lebanese educational system.

\section{Key historical cultural influences in Lebanon and the Lebanese national identity confusion}

There are deeply entrenched historical reasons that underlie the confusion about Lebanese national identity. After the First World War, the Middle East was divided according to the Sykes-Picot Agreement of 1916, by which France and Great Britain each took responsibility for the governance of a country (Ismail, 1972). Great Britain was allocated control of several areas including some Arab countries. France was allocated control of several countries, Lebanon included. When French forces landed in Beirut, Christians cheered their arrival whereas the Muslims watched the arrival of the French with grave apprehension (Salibi, 1988). This welcome presaged the acceptance of the French mandate which was enthusiastically accepted by the Christians and adamantly rejected by the Muslims (Salibi, 1988). This conflict was the result of the earlier occupation of Lebanon by the Muslim Turks (the Ottoman Empire) who had fought against the victorious western powers during the First World War (Ismail, 1972). Lebanese Muslims had been privileged under the Ottoman occupation, whereas under the western occupation the Christians were favoured by the then dominant power (Hudson, 1985). 
The Lebanese government and the French authorities decreed the creation of the State of Greater Lebanon (Picard, 2002). Leaders from the Christian majority, in consultation with the French mandate authorities, wrote the Constitution in 1926 (Hudson, 1985). This led in turn to the creation of the Lebanese Republic (Grafton, 2003). It is sometimes referred to as the Franco-Maronite ${ }^{1}$ creation of Greater Lebanon; a Maronite concept for Maronite purposes (Harris, 2006). It left the Muslims feeling alienated because they aspired to Arab unity (Hudson, 1985; Dagher, 2000).

Consequently, from the 1920s onward the Lebanese have developed contrasting ideas regarding the role and identity of the Lebanese polity (Dagher, 2000). At the two ends of the spectrum are what have been termed 'Lebanonism' (proponents being exclusively Maronite Christians) which views Lebanon as something detached from its Arab neighbourhood and 'Arabism' (proponents being Muslims) which views Lebanon as an integral component of the Arab world (Salibi, 1988; Harris, 2006). Lebanonism implied asserting the mythology of Phoenician origins and of attachment to the West, which could be labelled 'Maronite Nationalism' (Harris, 2006). Consequently, the two forces collided on every fundamental issue, impeding the normal development of the state (Salibi, 1988). In 1991, the word 'Lebanonisation' emerged, meaning the 'process of fragmentation of a state as a result of confrontation between diverse communities' (Harris, 2006, p. 1). This one word basically describes the disjointed infrastructure of Lebanon.

Christians and Muslims disagree on major concepts, such as Arabity, pluralism and cultural differences (Dagher, 2000). Even though Christians and Muslims remain in strong disagreement on how the Lebanese Republic ought to be generally interpreted and run, both sides have become equally convinced that there can be no viable alternative to Lebanon as territorially constituted (Salibi, 1988). 'Geography has constrained their coexistence while history has taught them that living together - for better or worse - was an irrevocable fate' (Dagher, 2000, p. 6).

The legacy of the confused national Lebanese identity is that 'both doctrinaire Christians and Muslims feel superior to and threatened by each other' (Hudson 1985, p. 91). The Muslims and the Christians of Lebanon did not exhibit a common identity in 1920, or in 1943 when the Lebanese Republic gained its independence on the basis of a 'polite fiction' (Salibi, 1988) of national unity among its people, or in 1958 when the Muslim and Christian Lebanese were in conflict with each other for six months over the issue of pan-Arab unity (Salibi, 1988). Clearly then, culture is not synonymous with nationality because even if individuals of a certain country are taught similar beliefs, attitudes and values, enormous differences will emerge (Devito, 2004). As Salibi (1988) described the 
Lebanese situation: 'to create a country is one thing, to create a nationality is another' (p. 19).

\section{The influence of Lebanon's multilingualism on its culture and educational systems}

Multicultural societies often 'contain a single dominant high-status group whose language is the lingua franca of the nation and a number of other ethnic groups whose languages are subordinate' (Hogg \& Vaughan, 2002, p. 427). This is what the current author refers to as cultural hegemony. Lebanon's multicultural society has equivocal levels of multilingualism, yet there is a distance between the various factions as a result of the aforementioned historical reasons. Although language is the most obvious sign of cultural difference within Lebanon, it is merely the symptom of a deeper symbolic rift. The root of the rift is religion, which is based on the historical clashes, which in turn resulted in the Lebanese national identity confusion.

Christian groups adopted the French language, traditions and customs. Muslim groups preferred to speak and to teach their children the Arabic language. Nevertheless, they adopted English as their second language since many came from Arab countries at a time during which Britain had power of authority. Given that language is one of the most distinct and clear markers of ethnic identity (Hogg \& Vaughan, 2002) and speech styles cue ethnic identity, each factionalised Lebanese culture conveys its individuality and its distinctiveness by the language it has adopted. For example, at a shop in the western side of Lebanon the salesperson would say the price in English or Arabic, whereas in the eastern side the price is mostly spoken in French or in Arabic. Interestingly, national greetings are almost always spoken in French: 'bonjour', 'bonsoir', or on the phone 'allo'. A good example of the complexity of the Lebanese culture is a common phrase used by the Lebanese, which combines all three languages: English, Arabic and French: ' $H i$, kifak, ça va'? Translation: 'Hi, how are you, fine?'

\section{The Lebanese language}

English began surreptitiously to seep into Lebanese-Arabic, leading to a fusion of languages into what is now referred to as 'Arabinglizi' (Al-Yousef, 1999). The grammatical structure of these words is derived from English roots and 'Arabified' (for examples see Appendix B). Hence, in addition to the already existing words with French roots, English words mutated into 'Arabic' words. These changes led 
to the following significant question: 'What is the language of Lebanon and what implications does it have for education?' Thonhauser (2001) researched this issue and reported that this simple question turned out to have not as simple an answer as might have been thought. The following example further elucidates the complexity of the linguistic divisions. A student coming to Lebanon from the University of Cambridge, UK, with the intention of strengthening her Arabic language, ended up leaving Lebanon without any improvement in her Arabic language, while polishing her English and French languages. She expressed her dismay by asking: 'Why don't the Lebanese like to speak their own language?' (cited in Al-Yousef, 1999). The question should not be generalised, as this is not the case with all Lebanese.

For historical reasons, the Lebanese Christians preferred to speak French and English instead of Arabic, as they tried to ignore the Arabic culture in order to strengthen their lifelong quest for independence from the Arab world (Dagher, 2000). The link between Arab and Islam is clear, however the link between Christians and Arabs is vague. The overwhelming majority of Arabs happen to be Muslims, hence Islam naturally underlines the sense of common ethnicity among most Arabs (Salibi, 1988). In addition, the foundation of the Arab world's identity and the expression of its specificity is the Arabic language. This coincides with the language of Islam, which can only be fully learned and embraced in Arabic (Dagher, 2000). This association between the Arabic language and Islam presents the real dilemma for eastern Christians (Dagher, 2000).

When a population perceives its ethnic identity to be a source of self-respect and pride, it accentuates it (Hogg \& Vaughan, 2002). It is common for some Christian Lebanese to de-emphasise their Arabic native language because of its connotations. Some Lebanese Christians refer to their language as Lebanese and not Arabic to emphasise the distinction. According to Salibi (1988), the Lebanese Christians have no doubt about the matter, they remain 'Lebanese regardless to which extent the outside world might choose to classify them as Arabs, because their language happened to be Arabic' (p. 27). Conversely, Muslims value their Arabic language. They are in a position where it is pragmatic to learn alternative languages to succeed in this modern era. Further, historic friction between Muslims and the French language seemed to have declined by the late $20^{\text {th }}$ century (Dagher, 2000). However, it is possible that this symbolic convergence has been interrupted by the most recent war that took place in July 2006.

Another example of Lebanon's multilingualism is provided on the streets where most placards combine languages (Al-Yousef, 1999; Thonhauser, 2001). This includes the colloquial Arabic, which follows no rules or grammar and is 
usually written in English script. Appendix C provides an example of a placard in Lebanon. A further uniqueness of the Lebanese multilingualism is in informal writings. For instance, 'ana mnie7' translates to 'I am fine'. Obviously, numerical numbers replace letters (e.g., the number ' 7 ' is used to replace the stressed ' $\mathrm{H}$ ' sound). The numbers chosen resemble the letters in the Arabic language (e.g., ' 7 ' is _ and ' 3 ' is _ in Arabic). However, official documents are usually written in Arabic, the official language, before being formally presented $^{2}$.

\section{The implication of language for the educational system}

Most private schools in Lebanon require students to learn two main languages (Arabic and either French or English) and a third minor language (English or French). Some even implement a curriculum containing all three languages with equal importance. In addition, schools implement formal Arabic which is different from spoken Arabic. Hence students are introduced to yet another new language, which ignores all prior experiences that have shaped the student's identity and cognitive functioning. Within a constructivist approach, educators would argue that teachers with students from linguistically diverse backgrounds should explicitly activate their students' prior knowledge. This knowledge embraces not only the information or skills previously acquired in formal instruction, but also the totality of the experiences that have shaped the learners' identity and cognitive functioning (Bismilla et al., 2005).

'The study of language in society illustrates how the members of a culture use verbal expression to define themselves and others in relation to one another' (Block \& Lemish, 2005, p. 154). Furthermore, the manner in which a person speaks (accent or language) affects the way s/he is evaluated by others. The reason does not envelop the probability that 'certain speech styles are intrinsically more pleasing than others, but rather because speech styles are associated with particular social groups that are consensually evaluated more or less positively in society' (Hogg \& Vaughan, 2002, p. 427). Similarly, in educational settings, students coming from diverse backgrounds are distinguished by their primary language (Au \& Blake, 2003). This is particularly true in a Lebanese classroom where students' ethnic backgrounds will be recognised by the manner in which they speak. Consequently, teachers will identify the social group to which students belong and, if the teachers hold preconceived biases and prejudices, discrimination for or against those students might occur. Not only could students be subjected to unfairness because of their language and ethnicity, but a teacher's perception of students' academic abilities could also be influenced by the students' language use (Galguera, 1998). 


\section{Religious cultural factors underpinning educational institutions}

Lebanon is dominated by its religions. Religion is not only part of the Lebanese culture, it is the catalyst that binds the individual subcultures internally. Casual or professional encounters between Lebanese people often entail indirect questions, with the intention of finding out the religion of the other person. The Lebanese population comprises different religious communities: the Christian (mainly Maronite, Greek Orthodox, Greek Catholics) and the Islamic (Sunnite Muslims, Shiite Muslims and Druze) (Salibi, 1988).

A research article by Jamali, Sidani \& Safieddine (2005) reported that 'the Muslims are estimated to comprise 70 per cent of the total resident population, with the remaining 30 per cent Christians' (p. 584). However, this is not entirely accurate because although Jamali, Sidani \& Safieddine (2005) claim that these figures are based on 2002 data from the United Nations Develoment Programme (UNDP) website (see http://www.undp.org/), the present author found that the UNDP website does not break down the Lebanese population by religion and only reports that the total Lebanese population was 3.5 million in 2003. In addition, several authors (Hudson, 1985; Dagher, 2000; Harris, 2006) assert that the demographic figures of the Lebanese population are considered a taboo, the belief being that if the actual numbers of people within different religions were known, those with the highest number might use this information as a basis for seeking greater political power. Thus, recently quoted demographic figures for Lebanon are usually spurious and often biased, because the latest available official figures date back to the 1932 census. Jamali, Sidani \& Safieddine's (2005) report tries to promote the idea that the Lebanese culture is characterised by the Muslim religion, however this might not actually be the case.

Religious symbols are part of everyday classroom life. Students identify themselves by using verbal or non-verbal expressions that typify their cultural background. This presents a problem if individuals hold negative bigotry views about others. Some Christian students often make the sign of the cross before taking an examination and some Muslim students often say 'Allah Akbar' meaning 'God is Great' when hearing the prayer from the Mosque. Therefore, teachers can easily identify the religious backgrounds of their students. Thus, if the teacher is able to recognise the students' ethnicity, it is possible that preconceived biases or prejudices could emerge. The solution is not easily found. The educational paradox is that there is an absence of the opportunity to acknowledge or discuss these differentials. Then again, discussing these locally controversial issues could have major consequences. 


\section{The Lebanese school system: the formal and the hidden curriculum}

In Lebanon, the public (i.e., the government) school system is poorly established. Across Lebanon, public schools suffer due to political interference, a spiralling number of students and dwindling government funds (Hajj, 2000). Hajj (2000) reports that the president of the public secondary school teachers' league addressed the following aspects during a seminar that took place in 2000:

- The issue of sectarianism being the most difficult obstacle standing in the way of public education.

- The concern for national unity is being jeopardised since rampant spread of sectarian politics is prevailing in schools all over Lebanon.

- The confessional troubles which are not being solved by the government.

- The suffering of students due to political interference in the administration of public education.

There are more Lebanese private sectarian schools than non-sectarian schools. In most cases, the geographical location of a school indicates the religion to which it subscribes. Parents choose a school for their children based on the types of values, ethos and traditions they want their children to follow.

Schools across Lebanon teach different versions of its history. Each community has its own collective memory, its own history, its own heroes, its anthem and its flags (Salibi, 1988; Dagher, 2000). Hence, Lebanon is permitting the young to be educated using highly selective and contradictory versions of its history (Picard, 2002). The Druze schools teach a new version of the history of Lebanon, which is radically different from the official version, as well as changing the curriculum to parallel the political ethos of the Druze community (Salibi, 1988). In contrast, the Sunnite schools follow the official government curriculum, upholding all the established symbols and traditions of their version of Lebanon (Salibi, 1988). As a result, students across Lebanon are acquiring their national citizenship in diversified ways, which causes intercultural conflict when they interact together academically and socially.

Most schools in Lebanon follow either the French baccalaureate model of the curriculum or align themselves with the American High School system. However, some schools adopt a mixture of the two. Each private school implements its own curriculum alongside the formal national Lebanese curriculum, which public schools are compelled to follow. The hidden curriculum encompasses a wider range of learning experiences than the formal curriculum. It will thus be discussed in more detail. 
A new curriculum was legally established in Lebanon in $1997^{3}$. Because religion and culture are interwoven and culture influences education, a religiouscultural educational conflict emerged. In 1999 Muslim intellectuals criticised the new school curriculum (Kayali, 1999). One general argument was that the curriculum copied the texts from western countries, neglecting to include Arabic traditions and customs. A specific debated issue was that the civic education textbooks emphasised the woman's role as an income earner and marginalised her role as mother and wife. Another complaint was that the science textbooks promoted improper sex education. Finally, the omission of the Islamic school of thought in the economic learning materials was considered a personal insult to the Islamic religion and totally disgraceful (Kayali, 1999).

One of the common factors in the many different curricula in Lebanon is that they rarely overtly address social issues. The liberal-secular ideology argues that if a school curriculum does not systematically include important information about the diversity of the society, it then causes major gaps in students' academic achievements (Gay, 2003; Brooks \& Thompson, 2005). Douglas (2002) claims that one profound source of unrest in this world is the failure of educational systems to bypass narrow ethnic and national interests and to provide teaching about differing belief systems and shared common values. In Lebanon, the curriculum lacks cohesive and general guidelines which would direct students on how to deal with the political and religious quandaries that are inherent in the ways in which cultural factors are negotiated in Lebanon.

Central to this paper is the argument that in Lebanese educational settings, individuals rarely converse about 'nondiscussable' issues. According to Barth (2002),

'nondiscussables are subjects sufficiently important that they are talked about frequently but are so laden with anxiety and fearfulness that these conversations take place only in the parking lot, the rest rooms, the playground, the car pool, or the dinner table at home.' (p. 8)

Major Lebanese 'nondiscussables' entail political and religious subjects. There is great fear that open discussions of these controversial issues will produce severe consequences. Some kind of harmony is maintained by not discussing the very issues that are at the heart of the Lebanese predicament. However, it seems that this type of harmony is only maintained inside the classroom. Substantial student arguments take place elsewhere. However, within school grounds, the confrontations are not severe, possibly because of the formation of the school system which is based on a hierarchical authority structure. Another explanation could be that it would depend on the school system into which the parents enrol their children. If the school parallels communal regional cultural values, then the 
students would maintain homogenous beliefs and customs. Whereas on university campuses all over Lebanon, students' constantly clash with each other over political and religious events (Tuttle, 1998; Zaatari, 1998; Ibrahim, 1999a; AbdulHussain, 2003; Abou Nasr, 2004; Hatoum, 2005, 2006; Ghazal, 2006a, 2006b). Appendix D provides a chronological list of some of the conflicts that occurred between university students in Lebanon.

A possible interpretation of these discords is that although students are sheltered from divergent cultures during school years, the exposure to diverse cultures is inevitable when they go to university because the choice of high-quality university education is limited. The educational dilemma is that it is unclear whether the discussion of these taboo topics in school would have led to positive consequences or not. When some views are exclusive and entrenched in a culture, productive dialogue is not only difficult to produce, but is also delicate in its nature because the unwrapping of some topics might lead to open hostilities and major ruptures.

From the liberal-secular perspective, it is argued that teachers' deficiency in openly discussing taboo topics leads to a lack of collective classroom coherence (Tatum, 2000; Barth, 2002; Shields, 2004). Thus, the liberal-secular ideology encourages teachers to develop classroom cultures that create shared student values (Kerfoot, 2004) by taking students' cultural differences into account (Shields, 2004). Shields (2004) points out that 'a successful education leader must attend to both social justice and academic excellence because one implies the other' (p. 38).

Tatum (2000) offers some reasons behind teachers' avoidance of provocative topics in the classroom. These include a lack of skill at discussing them, or a limited opportunity to explore these issues in their own education or a reluctance to lead such discussions for fear that they will generate classroom conflict. Barth (2002) asserts that giving these 'nondiscussables' such incredible power as to govern the school culture indicates that the same underlying problems will continue. The proposition to interrupt the cycle of biased behaviours, according to Tatum (2000), is that students need to understand how they operate in their society.

One would assume that the liberal-secular ideology would resolve social and academic problems in Lebanon, since hiding behind the taboo issues apparently did not resolve the quandaries. Then again, scrutinising the complexity of the Lebanese situation, coupled with the consideration of the consequences of the war that broke out in July 2006, leads to the inference that the liberal-secular ideology challenges what would be the obvious interpretation of the situation. The divergent factions differ sharply over the national interests and hold totally opposing views of what Lebanon is or should be. Thus, the quandary remains on how the educational system could unite the Lebanese multicultural students. 


\section{Politico-religious events in the educational field}

There is a rigid link between politico-religious events and the educational field in Lebanon. The Lebanese academic landscape reflects the confessional mosaic of the country in the way in which prominent universities were established by religious foundations. For example, as pointed out by Dagher (2000):

- The Shiites Supreme Council founded its Islamic University.

- The Sunni community established the al-Makassed.

- The Greek Orthodox administered the Balamand University.

- The Greek Catholic and Maronites founded Notre Dame University, Kaslik University, Law School of La Sagesse, and the Haigazian and Homenetmen Armenian institutions.

Lebanon 'currently accommodates 18 officially recognized private universities that are mostly patterned after the American credit system of higher education' (Abouchedid \& Nasser, 2002, p. 198).

The first example comes from the Lebanese University (LU), a public institution. 'During the war, its various branches were geographically, confessionally and ideologically divided between 'East' and West' and were the hotbed of political militancy' (Dagher, 2000, p. 129). In 1999, a plan was initiated to merge east and west campuses (Ibrahim, 1999b). In 2001, the proposal came into effect (Darrous, 2001). The proposal received mixed reactions from both LU academics and LU students. Members at Beirut branches (Muslims) generally supported the cabinet's decision, whereas Mount Lebanon-based staff and students (Christians) opposed the merger. The latter believed that merging the campuses would have dangerous political aspects and that the merger was aimed at suppressing students' and academics' political freedoms. Although students from the Progressive Socialist Party, which is a mostly Druze party, did not politically approve of the Christian opposition bloc, they supported them in their plan to fight the cabinet proposal. They justified their support on the basis that the decision entailed a political dimension and not an academic one. However, their long internal strife with the Shiites of Beirut, who happened to support the merger, is recognised (Darrous, 2001).

Another example from the school system consists of anecdotal information. Recently, in the eastern side of Lebanon, a Christian inter-sectarian conflict between the Lebanese Forces and the Free Patriotic Movement (FPM) has been escalating. The FPM has adopted orange as its colour, resulting in the whole country linking the orange colour with that movement. Accordingly, this gives rise to easy differentiation between people on political lines. Now, to avoid being 
politically differentiated, it appears that some people are avoiding wearing any orange garment. It is argued that this behaviour has contaminated school grounds. The affiliation of teachers or students who wear the orange colour could be recognised, and thus biased behaviours could emerge toward and from the opposing group. This is in line with Hofstede \& Hofstede's (2005) theory that in collectivist cultures, students tend to expect preferential treatment when they share common ideologies with the teacher. Taking into account that 'prejudices and stereotypes influence teachers' perceptions of and behaviour toward students but also that similar attitudes influence students' perceptions of and behaviour toward teachers' (Galguera, 1998, p. 412).

If these kinds of events are generalisable throughout Lebanese classrooms, then it is possible that there is an absence of healthy teacher-student relationships where teachers promote learning (Wolk, 2003), establish rapport (Mendes, 2003) and enhance student achievements (Marzano \& Marzano, 2003). As a consequence, the concept of educating the 'whole' child (Wolk, 2003) fails since it depends on school bonding, a healthy school climate, teacher support, and student engagement (Blum, 2005).

Some liberal-secular ideologists would argue that students require unconditional acceptance to flourish (Kohn, 2005), and claim that education that is just and caring provides opportunities for students to make sense of complex topics such as religion and ethnicity (Shields, 2004). Brooks \& Thompson (2005) emphasise that teachers have a 'professional responsibility to see the diverse cultural value systems of their students with an open mind, as free as possible from their own value systems' (p. 50). Accordingly, it is suggested that toxic school cultures that are monopolised by politics and religion are not only preserving hostile discriminatory feelings in the new generation, but are also affecting students' learning and personal growth.

A logical conclusion to be drawn from the preceding arguments is that, on the one hand, there are the 'nondiscussables' and, on the other hand, there are individuals who are parading their political affiliations. This is a threatening combination and a potential source of conflict. The problems are there for everyone to see, yet they cannot be discussed within the formal educational context. This suggests an unhealthy state of affairs in the classroom. The very things that divide people are the exact things that are not allowed to be discussed. Although multiple sources of variations exist within cultures, one's early experiences tend to become organised into definite systems of thought (Jackson \& Wasson, 2002). Even more, in a multicultural country such as Lebanon, one would assume that education is multicultural, which means 'education that promotes educational equity for all learners' (Armstrong, Henson \& Savage, 2005, p. 115). Evidently, this is not the case. 


\section{Conclusion}

This paper recognised the fragmentation of Lebanon. Lebanonism became a byword that describes the disjointed infrastructure of Lebanon. During the writing of this paper, another war broke out in Lebanon which changed its whole panoramic view. Political alliances shifted and were reconstructed on the bases of political and personal gains rather than religious grouping. The war's implications for the educational system are countless. Other than reintegrating bias and prejudice feelings in the older generation, the younger generation is now living the harsh reality of intolerance which were previously just anecdotes passed on to them. Multiple Lebanese cultures continue to exist, but in a volatile state. This has produced serious consequences which will lead to future political and social conflicts. These, in turn, will undoubtedly have significant implications on the educational system. The Lebanese quandary is, among other things, an educational challenge.

The aim of education in general is bound by a universal purpose - to educate the students, but each particular society has specific aspirations and methods which make it unique (Noddings, 2005). A liberal-secular argument is that for successful teaching and learning in multi-linguistic and multicultural societies, students must gain an understanding of the differences and similarities of the various cultures. As Brooks \& Thompson (2005) stated, 'it is crucial to help students consider diversity, understanding, and the places where the two intersect and clash' (p. 48). In order to promote a unified national culture, students who are prospective teachers need to encounter more cross-cultural experiences so that they can develop favourable personal and professional beliefs about diverse learners (Garmon, 2004). However, the application of liberal-secular educational theories in Lebanon is contestable.

The history of Lebanon is marked by conflict and filled with turmoil, dismay and suffering. It is difficult to read one book or one paper that captures the whole Lebanese picture. Many books have been written about Lebanon and yet none capture the reality. Lebanese writers portray the view of the aspect with which they are or choose to be aligned, thus failing in their efforts to be unbiased. No Lebanese person who has lived in Lebanon can be truly unbiased. Each group, having observed the death and suffering of its own members caused by an opposing party, cannot be totally objective when claiming facts and events. Foreign writers, unfamiliar with the Lebanese culture, also fail to convey a view of Lebanon that is free from bias. They might investigate many issues, interview different political parties, but there is something about Lebanon that a person cannot fully comprehend unless $\mathrm{s} / \mathrm{he}$ has lived there. 
This paper has illustrated the difficulties in attempting to describe Lebanese culture. The Lebanese people are, on the one hand, united by a common fate, yet, on the other hand, are separated by religious doctrines and political ideologies. Although the profound and negative influences of the culture on the educational system are recognised, solutions have yet to be determined.

\section{Notes}

1. Maronite is a dominant Christian sect in the Middle East.

2. Source: personal communication with a senior civil servant in the Lebanese government.

3. Public Law number 10227.

\section{Acknowledgements}

I would like to thank Professor Paul Cooper of the University of Leicester, UK, for the help and support in the preparation of this paper.

Linda Akl received the BS degree in Communication Arts from the University of the State of New York in 1996, and the MA degree in Educational Management from the Lebanese American University in 2002. She is currently an EdD candidate at the University of Leicester, UK. She was formerly an instructor in education at Notre Dame University in Lebanon. Her research interests include intercultural educational engagements, gender inequality in management and education of ethnic minorities. Here-mail address is: lakl105@hotmail.com

\section{References}

Abdul-Hussain, H. (2003) Student polls show support for pro-government groups; FPM sees setbacks at most universities. The Daily Star (Lebanon), 30 December. Available online at: http://www.dailystar.com.lb/default.asp

Abouchedid, K., \& Nasser, R. (2002) Assuring quality service in higher education: registration and advising attitudes in a private university in Lebanon, Quality Assurance in Education, Vol. 10(4), pp. 198-206.

Abou Nasr, M. (2004) LU campus sealed after fight breaks out between Amal and Hizbollah students: three injured in fracas; conflicting stories circulating. The Daily Star (Lebanon), 7 February. Available online at: http://www.dailystar.com.lb/ default.asp 
Albright, E., \& Kugler, E. G. (2005) Increasing diversity in challenging classes, Educational leadership, Vol. 62(5), pp. 42-44.

Al-Yousef, Y. (1999) The very resistible rise of Arabinglizi. The Daily Star (Lebanon), 15 June. Available online at: http://www.dailystar.com.lb/default.asp

Anjum, A., Baarsen, B. V., Boratav, H. B., Carson-Arenas, A., Gibbs, M. S., Goodrich, C., Hsu, D., Pan, K., Perrino, C. S., Rashid, T., Sigal, J., \& Van der Pligt, J. (2005) Crosscultural reactions to academic sexual harassment: effects of individualist vs. collectivist culture and gender of participants, Sex Roles: A Journal of Research, Vol. 52(3-4), pp. 201-216.

Arends, R. I., Tannenbaum, M. D., \& Winitzky, N. E. (2001) Exploring Teaching: An Introduction to Education (2 ${ }^{\text {nd }}$ edition). New York: McGraw-Hill Higher Education.

Armstrong, D. G., Henson, K. T., \& Savage, T. V. (2005) Teaching Today: An Introduction to Education ( $7^{\text {th }}$ edition). Upper Saddle River, NJ: Pearson Prentice Hall.

$\mathrm{Au}, \mathrm{K} . \mathrm{H}$., \& Blake, K. M. (2003) Cultural identity and learning to teach in a diverse community: findings from a collective case study, Journal of Teacher Education, Vol. 54(3), pp. 192-206.

Barth, R. S. (2002) The culture builder, Educational Leadership, Vol. 59(8), pp. 6-11.

Bazron, B., Fleischman, S., \& Osher, D. (2005) Creating culturally responsive schools, Educational Leadership, Vol. 63(1), pp. 83-84.

Berger, P. L. (2003) Religions and globalisation, European Judaism, Vol. 36(1), pp. 4-11.

Bernstein, B. (1970) Education cannot compensate for society, New Society, Vol. 15, pp. 344-391.

Biehler, R., \& Snowman, J. (2003) Psychology Applied to Teaching (10 ${ }^{\text {th }}$ edition). Boston: Houghton Mifflin Company.

Bismilla, V., Chow, P., Cohen, S., Cummins, J., Giampapa, F., Leoni, L., Sandhu, P., \& Sastri, P. (2005) Affirming identity in multilingual classrooms, Educational Leadership, Vol. 63(1), pp. 38-43.

Block, L. R., \& Lemish, D. (2005) "I know I'm a Freierit, but...": how a key cultural frame (en)genders a discourse of inequality, Journal of Communication, Vol. 55(1), pp. 38-55.

Blum, R. W. (2005) A case for school connectedness, Educational Leadership, Vol. 62(7), pp. 16-20.

Brooks, J. G., \& Thompson, E. G. (2005) Social justice in the classroom, Educational Leadership, Vol. 63(1), pp. 48-52.

Dagher, C. H. (2000) Bring Down the Walls: Lebanon's Post-War Challenge. New York: Palgrave.

Darrous, S. (2001) LU students deeply divided by plan for proposed merger. The Daily Star (Lebanon), 15 May. Available online at: http://www.dailystar.com.lb/default.asp

Devito, J. A. (2004) The Interpersonal Communication Book (10 th edition). Boston: Pearson Education.

Douglass, S. L. (2002) Teaching about religion, Educational Leadership, Vol. 60(2), pp. 32-36.

Eggen, P. D., \& Kauchak, D. P. (2003) Learning and Teaching: Research-Based Methods ( $4^{\text {th }}$ edition). Boston: Pearson Education. 
Evans, E. M., Schweingruber, H., \& Stevenson, H. W. (2002) Gender differences in interest and knowledge acquisition: the United States, Taiwan and Japan, Sex Roles: A Journal of Research, Vol. 47(3-4), pp. 153-168.

Femiano, A. C., Ludlow, L. H., Mahalik, J. R., Morray, E. B., Slattery, S. M., \& Smiler, A. (2005) Development of the conformity to feminine norms inventory, Sex Roles: A Journal of Research, Vol. 52(7-8), pp. 417-436.

Galguera, T. (1998) Students' attitudes toward teachers' ethnicity, bilinguality, and gender, Hispanic Journal of Behavioural Sciences, Vol. 20(4), pp. 411-429.

Garmon, M. A. (2004) Changing preservice teachers' attitudes/beliefs about diversity: what are the critical factors? Journal of Teacher Education, Vol. 55(3), pp. 201-214.

Gay, G. (2003) The importance of multicultural education, Educational Leadership, Vol. 61(4), pp. 30-35.

Ghazal, R. (2006a) NDU students overcome security to get advocacy group onto campus. The Daily Star (Lebanon), 23 March. Available online at: http://www.dailystar.com.lb/ default.asp

Ghazal, R. (2006b) PSP-Amal brawl forces LAU to shut down: instigators to face expulsion. The Daily Star (Lebanon), 27 May. Available online at: http://www. dailystar.com.lb/default.asp

Grafton, D. D. (2003) The Christians of Lebanon: Political Rights in Islamic Law. London: Tauris Academic Studies.

Hajj, J. D. (2000) 'Sectarian influence' is harming schools. The Daily Star (Lebanon), 31 March. Available online at: http://www.dailystar.com.lb/default.asp

Harris, W. (2006) The New Face of Lebanon: History's Revenge. Princeton, NJ: Markus Wiener Publishers.

Hatoum, M. (2005) Violence erupts at Arab University: fight between opposition and loyalist students leaves 2 wounded. The Daily Star (Lebanon), 24 March. Available online at: http://www.dailystar.com.lb/default.asp

Hatoum, M. (2006) Seven injured in LF-FPM student clashes. The Daily Star (Lebanon), 4 May. Available online at: http://www.dailystar.com.lb/default.asp

Hofstede, G., \& Hofstede, G. J. (2005) Cultures and Organizations: Software of the Mind. New York: McGraw-Hill.

Hogg, M. A.. \& Vaughan, G. M. (2002) Introduction to Social Psychology ( $3^{\text {rd }}$ edition). Frenchs Forest, Australia: Pearson Education Australia.

Hudson, M. C. (1985) The Precarious Republic: Political Modernization in Lebanon. Boulder, CO: Westview Press.

Ibrahim, A. (1999a) LU fistfight thought to have political undertones. The Daily Star (Lebanon), 3 December. Available online at: http://www.dailystar.com.lb/default.asp

Ibrahim, A. (1999b) University unity addressed at forum. The Daily Star (Lebanon), 4 June. Available online at: http://www.dailystar.com.lb/default.asp

Iskold, L. V. (2002) Integrating culture, language and technology, Academic Exchange Quarterly, Vol. 6(4), pp. 103-108.

Ismail, A. (1972) Lebanon: History of a People. Beirut: Dar Al-Makchouf.

Jackson, M. H., \& Wasson, D. H. (2002) Assessing cross-cultural sensitivity awareness: a basis for curriculum change, Journal of Instructional Psychology, Vol. 29(4), pp. 265-277. 
Jamali, D., Sidani, Y., \& Safieddine, A. (2005) Constraints facing working women in Lebanon: an insider view, Women in Management Review, Vol. 20(8), pp. 581-594.

Kayali, I. (1999) Textbook mistakes cause Muslim ire. The Daily Star (Lebanon), 14 October. Available online at: http://www.dailystar.com.lb/default.asp

Kerfoot, K. (2004) Attending to weak signals: the leader's challenge, Pediatric Nursing, Vol. 30(1), pp. 79-82.

Kluth, P., \& Straut, D. (2001) Standards for diverse learners, Educational Leadership, Vol. 59(1), pp. 43-46.

Kohn, A. (2005) Unconditional teaching, Educational Leadership, Vol. 63(1), pp 20-24.

Marzano, R. J.2 \& Marzano, J. S. (2003) The key to classroom management, Educational Leadership, Vol. 61(1), pp. 6-13.

Mendez, E. (2003) What empathy can do, Educational Leadership, Vol. 61(1), pp. 56-59.

Napoliello, S., \& Powell, W. (2005) Using observation to improve instruction, Educational Leadership, Vol. 62(5), pp 52-56.

Noddings, N. (2005) What does it mean to teach the whole child? Educational Leadership, Vol. 63(1), pp. 8-13.

O'Brien, M. U., Payton, J., Resnik, H., \& Weissberg, R. P. (2003) Evaluating social and emotional learning programs, Educational Leadership, Vol. 60(6), pp. 46-50.

Picard, E. (2002) Lebanon: A Shattered Country (revised edition). New York: Holmes \& Meier Publishers.

Salibi, K. (1988) A House of Many Mansions: The History of Lebanon Reconsidered. Los Angeles, CA: University of California Press.

Schaps, E. (2003) Creating a school community, Educational Leadership, Vol. 60(6), pp. 31-33.

Shields, C. M. (2004) Creating a community of difference, Educational Leadership, Vol. 61(7), pp. 38-41.

Tatum, B. D. (2000) Examining racial and cultural thinking, Educational Leadership, Vol. 57(8), pp. 54-57.

Thonhauser, I. (2001) Multilingual education in Lebanon: 'arabinglizi' and other challenges of multilingualism, Mediterranean Journal of Educational Studies, Vol. 6(1), pp. 49-61.

Tuttle, R. (1998) LAU altercation before students' right victory. The Daily Star (Lebanon), 16 May. Available online at: http://www.dailystar.com.lb/default.asp

Wolk, S. (2003) Hearts and minds: classroom relationships and learning interact, Educational Leadership, Vol. 61(1), pp. 14-18.

Zaatari, M. (1998) University poll ends in faculty brawl. The Daily Star (Lebanon), 21 February. Available online at: http://www.dailystar.com.lb/default.asp 


\section{APPENDIX A}

Schematic illustrating the Key Elements of the Lebanese Culture

Lebanese Culture

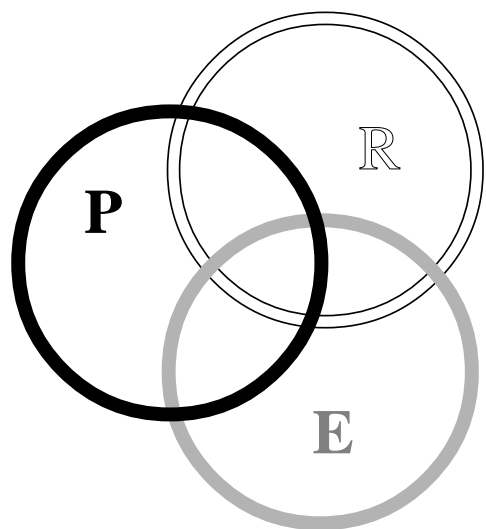

$\mathbf{P}=$ Political Culture

$\mathrm{E}=$ Ethnic Culture

$\mathbb{R}=$ Religious Culture

APPENDIX B

Glossary of Arabinglizi

\begin{tabular}{|l|l|}
\hline \multicolumn{1}{|c|}{ Word } & \\
\hline angarit & to become angry \\
golargi & goalkeeper \\
hawvaret & to 'hoover' (to clean - from the vacuum cleaner brand 'Hoover') \\
sayyiva & to save something on a computer \\
dapris & to get depressed \\
reglij & to regulate \\
cancil & to cancel \\
jagal & gigolo \\
cdeeyet & plural of CD \\
emaiyilla & to e-mail \\
fawella & to fill it up \\
\hline
\end{tabular}




\title{
APPENDIX C
}

\section{An Example of Lebanon's Multilingualism taken from Thonhauser (2001)}

\begin{abstract}
'Yeprad Amseyan \& Sons. Repair - Frigidaires \& Woching Machines'
The sign addresses customers with essentially the same message in two different languages and two different scripts. There is even a French word (Frigidaires), which is simply a brand name in a somewhat plural feature of Lebanese communication. The spelling of 'Woching Machines' reflects the dominance of spoken discourse in everyday language use. Orthography seems to rank second. The visual representation of a familiar combination sound is enough.
\end{abstract}

\section{APPENDIX D}

\section{Conflicts between University Students in Lebanon as reported by The Daily Star, a Leading English Language Lebanese Newspaper}

\begin{tabular}{|c|l|}
\hline 1998 & $\begin{array}{l}\text { A fistfight broke out between the two competing blocs; one holds supporters } \\
\text { of the Communist Party and Hizbollah and the second bloc groups supporters } \\
\text { of the Amal Movement, the Baath Party, and the Syrian Social Nationalist } \\
\text { Party during the election of a new student council at LU (Zaatari, 1998). }\end{array}$ \\
\hline 1998 & $\begin{array}{l}\text { Students clashed over the election of the student council at LAU Beirut } \\
\text { (Tuttle, 1998). }\end{array}$ \\
\hline 2003 & $\begin{array}{l}\text { Students from the Amal Movement clashed with students from PSP at the } \\
\text { LU Beirut campus (Ibrahim, 1999a). } \\
\text { (Abdul-Hussain, 2003). }\end{array}$ \\
\hline 2004 & $\begin{array}{l}\text { Students clashed between proponents of Amal and Hizbollah at LU Sanayeh } \\
\text { (Abou Nasr, 2004). }\end{array}$ \\
\hline 2005 & $\begin{array}{l}\text { Students from the opposition and pro-Syrian factions clashed at the Arab } \\
\text { University in Beirut (Hatoum, 2005). }\end{array}$ \\
\hline 2006 & $\begin{array}{l}\text { Students from the FPM overcame the security checkpoint at NDU to direct } \\
\text { a political meeting, which the administration had banned (Ghazal, 2006a). }\end{array}$ \\
\hline 2006 & $\begin{array}{l}\text { Students from the Amal Movement brawled with students from the PSP } \\
\text { movement at LAU Beirut campus (Ghazal, 2006b). } \\
\text { election seats for the student council (Hatoum, 2006). }\end{array}$ \\
\hline
\end{tabular}




\section{Abbreviations:}

- Lebanese University (LU)

- Lebanese American University (LAU)

- Notre Dame University (NDU)

- Lebanese Forces (LF)

- Free Patriotic Movement (FPM)

- Progressive Socialist Party (PSP) 